\title{
Spatial Patterns of Second Home Development as Part of Rural Landscapes. A Case Study of Apuseni Nature Park
}

\author{
Ioana Alexandra CIUPE *1 \\ * Corresponding author \\ 1 Babeş-Bolyai University, Faculty of Geography, Territorial Identities and Development Research Centre, Cluj-Napoca, ROMANIA \\ $\triangle$ alexandra.ciupe@yahoo.com (D) https://orcid.org/oooo-0oo3-3308-3191 \\ DOI: 10.24193/JSSPSI.2021.8.06 \\ https://doi.org/10.24193/JSSPSI.2021.8.06
}

K e y w o r d s: second home tourism, GIS, cluster analysis, PCA, landscape typology, landscape classification, spatial distribution, spatial differentiation

\begin{abstract}
A B S T RA C T
During the last decades, against the backdrop of radical social and economic restructuring, the rural environment has changed fundamentally, arising new social and economic dynamics and cultural realities. The second homes development has significantly contributed to this process and created major challenges for the need to protect the rural character. Therefore, with the purpose of integrated and sustainable spatial planning, a detailed acquaintance of second homes' spatial differentiation as part of contemporary rural landscapes, is a core prerequisite. This study aims to determine the second homes spatial patterns in relation to the main characteristics of the local environment, and to create a practical cornerstone for stakeholders concerned with integrated planning of second home tourism. In order to achieve these goals, this research used five major datasets related to land cover, elevation, climate, management system for protected areas and other social aspects (e.g. tourism, native settlements). Twenty-three variables were defined using GIS and subsequently assigned to grid cells with a size of $1.5 \mathrm{~km}^{2}$. To reduce the dimensionality of spatial datasets, Principal Components Analysis (PCA) was performed, resulting seven components that explained $77.2 \%$ of the variation. The PCA score was the subject of k-means cluster analysis that revealed nineteen landscape types. Finally, the spatial location of second homes is overlaid with the identified rural landscapes. This approach shows plenty of hidden nuances of second home tourism and facilitates its integration in both spatial, socio-cultural, and administrative dimensions.
\end{abstract}

\section{INTRODUCTION}

In Romania, in recent decades, following the transition process from the over-centralized economy to the market economy, rural areas and particularly the peripheral ones have been affected by the labour shedding in the primary sector (e.g. mining, agriculture, forestry, fishery, quarrying) and, consequently, the outmigration and economic decline (Mihalache, 2020; Surd et al., 2007).

According to Smailes (2002) changes in the social composition of rural populations or the so-called 'rural dilution' are caused by declining levels of primary production, whereas "in-migration of new elements (retirement, long-distance commuting, lifestyle migration) is occurring" (p. 79). In this regard, Müller (2004) claimed that the role of second homes development in rural transformation could be perceived both as a factor (e.g. changes in socio-cultural composition, property market, landscape structure) and as an effect (of economic restructuring and outmigration) (p. 245). Paris (2006) reiterated this view, noting that second home development is part of both the process of change and the creation of places (p. 8).

Thus, since the former rural non-market economy system has been replaced by a more service- 
oriented or mixed economy (Mihalache, 2020; Woods, 2005), second home development emerged as a response of the rural crisis caused by the restructuring process (Müller, 2002a, p. 343). Invariably, these new elements generate mutations in the natural, cultural, economic, and social systems of the local environment. As Banini and Ilovan (2021a) stated, the identity or the specific character of a place/territory is no longer a matter of "closed, self-referential process, referable to a cohesive and culturally homogeneous settled community, but as a result of dynamic, transcalar, material and unmaterial interconnections" (p. 4).

Thus, the dramatic and relatively permanent changes (compared to other forms of tourism), produced by second home ownership could turn into an inflow of new perceptions, desires, and objectives (cf. Jaakson, 1986; Marcouiller et al., 1996; Müller, Hall and Keen, 2004), processes of displacement of the local population (see Hall, 2014; Müller, Hall and Keen, 2004), commodification of natural and cultural milieus (Paris, 2006), spatial and / or social segregation (Halseth, 2004; McHugh, 2006, 2007; McHugh and Mings, 1996), changes in the spatial and morphological structure of native settlements (Mika, 2013), and so on.

However, the positive side of second home development should not be overlooked. For example, it has been suggested that second home users can act as ambassadors for the host areas "promoting their produce and virtues", get involved in the local entrepreneurial environment, generate new opportunities, and increase inflows of intellectual capital (Müller and Hall, 2004, p. 276). Moreover, the support of local communities could be significantly stimulated through the particular second home users' consumption patterns similar to both locals and tourists (Adamiak, 2014; Czarnecki, 2014; Czarnecki, Sireni and Dacko, 2021; Flognfeldt and Tjørve, 2013; Hoogendoorn, Visser and Marais, 2009; Müller, 2002a).

All things considered, the new rural realities have become the subject of community policies that promote multifunctional rural development. For instance, the European Union Regulation ([EC] no. 1305/2013, para. 18) calls for diversified development covering agricultural and non-agricultural businesses, as well as the "projects that bring together agriculture and rural tourism through the promotion of sustainable and responsible tourism".

Therefore, farm diversification seeks to mitigate the level of dependence on the primary sector (Woods, 2005) and stimulates the ecological and sociocultural functions mainly through tourism industry, as an alternative for sustainable development (Kiss et al., 2020, p. 4; Marescotti, 2003, p. 5; Renting et al., 2009, p. 116). According to Czarnecki (2014), because second home development stimulate the local economy, it has a lot in common with the concepts of "multifunctional and endogenous development" (p. 154). Consequently, spatial planning plays a key role in the monitoring and 66 sustainable development of second homes, even if this target may be hampered by their interference with miscellaneous institutional actors from fields such as "land-use planning, infrastructure planning and environmental policy" (Hall, 2015, pp. 4-5). Moreover, since second home development is characterized, inter alia, by dynamism, spontaneity, and significant consumption of space (Mika, 2013, p. 509), the direction for future developments should consider improving environmental quality, creating a better investment and development environment that meets the needs of local communities, and preserving recreational areas (United Nations, 2008, Box 1, p. 2).

To meet these considerations, first and foremost it is necessary to ensure knowledge and awareness of the geographic particularities of second home phenomena, secondly, of the contemporary local rural reality and, finally, the relationships of them. Thus, one of the useful tools in this regard is the spatial pattern analysis that constitutes "a prerequisite to understanding the complicated processes governing the distribution of spatial phenomena" (Chou, 1995, p. 365). Recently, plenty of commentators have been concerned about the spatial patterns of second home development from both a predominantly theoretical (Mika, 2013; Müller, Hall and Keen, 2004) and applied perspective (Adamiak, 2016; Jeong et al., 2014; Müller, 2004; Pitkänen, 2008; Roca et al., 2011; Soszyński et al., 2017).

After all, two matters need to be taken into consideration. First, it is necessary to identify the geographical differentiation of specific characteristics of the area in which second homes are located. Accordingly, Banini and Ilovan (2021b) point out that place/territorial identities should be considered "as resources for development at the local scale and a factor ensuring community resilience" (p. 252). Secondly, to mitigate its status of 'marginal form of tourism' (Cohen, 1974, p. 540) or that of 'inessential houses' (Wolfe, 1965, p. 7), second home development should be 'connected' to the local general tourism system (Ciupe, 2020) through support activities in promoting, adjusting, and orienting the secondary tourist resources towards the seasonal population (Ciupe, 2021).

Therefore, the major objective of this study was to determine the main spatial patterns of second homes in relation to the host rural landscapes in a detailed manner. Additionally, the secondary objective was to achieve a useful framework for decision-makers and public authorities regarding future strategic tourism planning. To this end, after this introduction, section 2 gives a brief overview of the international experience regarding the second home locations, followed by a general description of the study area. This is completed by a presentation of the methodology used, inspired by a multivariate classification of landscape approaches. Section 3 presents the resulted 
landscape types and their relationship with the second homes' spatial distribution. Finally, the major conclusions are summarized in section 4.

In short, the examination and quantification of relevant characteristics of rural landscapes are required to assist local spatial planning authorities and policy makers to understand, and therefore, to protect the area of their jurisdiction (Jellema et al. 2009, p. 161; Lee, Elton and Thompson, 1999, p. 23).

Accordingly, due to the detailed approach of spatial differences in relation to the physical, cultural, and social environments (including tourism), the results of this study could be a useful tool for policymakers and local authorities to integrate second home development into the broad sustainable planning. Moreover, this research may also contribute to the new insights of second homes' spatial distribution in relation to the contemporary rural landscapes.

\section{THEORY AND METHODOLOGY}

\subsection{Location factors of second homes}

The second home phenomenon is widespread throughout the world. However, for obvious reasons, its spatial distribution is related to the geographical context. One of the key factors associated with second homes' spatial organization is the transportation/spatial accessibility of the second home. Müller (2006, p. 348) claimed that second home tourism is characteristic of regional rather than national mobility. This is the case of Romania. Thus, considering the geographical particularities of each country or region, in general, the second home ownership demand tends to decrease as the distance from the primary residence increases (Hall and Müller, 2004; Hoogendoorn and Visser, 2004; Müller, 2004; Pitkänen, 2008). Moreover, in the academic literature, based on the time-distance factor, the labels such as weekend area/home and vacation area/home are often used (cf. Hall and Müller, 2004; Müller, 2002b). Accordingly, second homes located in weekend zones favour frequent and short-term visits, whereas those located in vacation zones allow long-term visits and a high likelihood of local purchases (Müller, 2002b, 2006; Hiltunen and Rehunen, 2014).

However, as Hall and Müller (2004) point out, "amenity-rich areas disturb the otherwise very regularly distance - declining pattern of second homes" (p. 10). It has been demonstrated that among the most popular areas for second home location are the attractive amenity-rich coastal, mountain or countryside landscapes, national parks or other scenic quality areas (e.g. Adamiak, 2016; Müller, 2004, 2006; Paris, 2011; Pitkänen, 2008; Soszyński et al., 2017 and so on).

More specifically, international experience reveals that second homes may be found: in the vicinity of water bodies, reservoirs, rivers, streams, or sea; in the proximity of forests or in permanent forest clearings; in mountainous areas with high altitudes and other places with scenic views; in protected natural and cultural landscapes; in groups integrated in, attached to, or isolated from the main villages, etc. (cf. Adamiak, 2016; Hiltunen and Rehunen, 2014; Mika, 2013; Pitkänen, 2008; Roca et al., 2011; Sievänen, Pouta and Neuvonen, 2007; Soszyński et al., 2017).

Generally, these amenity-rich or, more precisely, so-called hot spot areas (see Müller, 2004, pp. 247-248) imply development of purpose-built second homes and stand out through opportunities for recreational activities and a higher demand than the supply for second home areas. On the contrary, 'disappearing regions' generally concentrate inherited and/or converted second homes in areas with economic and demographic decline and a higher supply of property than demand (Müller, 2004, 2006; Müller, Hall and Keen, 2004).

Closely related to the last matter, a third factor that has a spatial influence on second home ownership includes the emotional ties created through childhood experiences or family roots with the host area (Müller, 2006, p. 337).

Moreover, second home locations are also dependent on the availability of land, urban regulations, planning policies and property prices (Flognfeldt and Tjørve, 2013; Hall and Müller, 2004; Mirani and Farahani, 2015; Müller, 2006). According to Müller (2006), the higher assessed property values are found especially in major tourist destinations (p. 334).

On the other hand, the presence of services in the host area generated an increasing interest among second home users. A number of studies have identified the presence of (generally, purpose-built) second homes in popular tourism resorts/destinations (Kauppila, 2010; Komppula, Reijonen and Timonen, 2008; Müller, 2005; Soto and Clavé, 2017). This trend might be the result of previous visits of second home users as traditional tourists (Flognfeldt and Tjørve, 2013, p. 345) or similar leisure needs of the two categories (Adamiak, 2014, p. 367).

\subsection{Study area}

Apuseni Nature Park is a Protected Landscape (IUCN Protected Area Category V). According to International Union for Conservation of Nature (2013), category V represents "a protected area where the interaction of people and nature over time has produced an area of distinct character with significant ecological, biological, cultural and scenic value" (p. 20). The protected landscape covers an area of approximately 75,784 hectares (according to Apuseni Nature Park Administration, 2016) and overlaps parts of three counties: Cluj, Alba and Bihor (Fig. 1). 


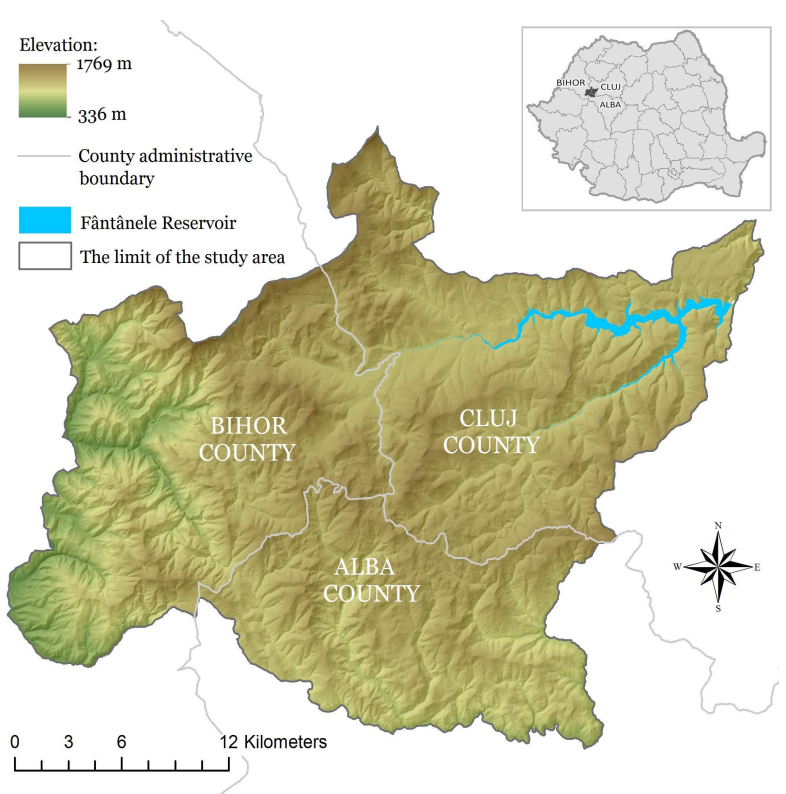

Fig. 1. Location map of the study area.

However, for the purpose of this study, the limit considered does not entirely correspond to the official one and includes 55 villages and two hamlets, of which six are rural municipalities.

The very limited employment opportunities, the depopulation process through out-migration, and the promotion of multifunctional development policies have made of tourism one of the most viable solutions for local economic support (Surd et al., 2007). Considering this, two municipalities have been declared resorts of local interest recently (Arieșeni and Albac, nos. 4 and 7 in Fig. 3). In addition, there are still several important tourism poles such as Vârtop ski resort (no. 8, Fig. 3), Fântânele lakeside resort (no. 2, Fig. 3), Boga holiday village (no. 9, Fig. 3), which are distinguished by a large proportion of second homes, Padis tourist zone (no. 10, Fig. 3), and Ic Ponor holiday village. Undoubtedly, due to the well-defined geographical identity of the area (Boțan and Ilovan, 2006), tourist flows of different intensity are spread throughout the Apuseni Nature Park. For instance, according to Apuseni Nature Park Administration (2016), there is an impressive number of caves and hollows (around 1,500) and plenty of nature reserves and monuments (up to 52, with botanical, floristic, landscape, geological, mixed, and speleological character).

The morphological identity of the relief has conditioned the settlement system's structure (Boțan and Ilovan, 2006). Thus, according to the classification of Surd, Constantin and Nicula (2017), of the village hearth's structure, in this area, nucleated settlements are often represented by the municipalities, whereas those scattered and dispersed can be found up to the highest altitudes. Furthermore, the relief conditions the development of a subsistence agriculture (Boțan and Ilovan, 2006). The forests, beyond the recreational function, have played an important role in the history of 68 spiritual habits, traditional architecture, and trade in craft products (Boțan and Ilovan, 2006).

Other important identity elements are the hydrography, the "social-historical conditions, the specificity of spatial individualising, the specificity of the climate, the features of demography, of tourism, and of the ethnographic component" (Boțan and Ilovan, 2006).

In short, based on the attractiveness of the natural, socio-cultural, and historical characteristics of landscapes, the area has attracted plenty of second homes that, according to field research, exceed double the number of classified and unclassified accommodation units.

\subsection{Data collection and procedures}

The methods used in this study were based on previous approaches on the multivariate classification analysis of landscapes (i.e. Chuman and Romportl, 2010; Fňukalová and Romportl, 2014; Pecher et al., 2013; Van Eetvelde and Antrop, 2009; Yang et al., 2020 - for the parametric approach), complemented by the introduction of the tourist component.

According to Van Eetvelde and Antrop (2007, cited by Van Eetvelde and Antrop, 2009, pp. 163-164) in the multivariate classification analysis of landscapes, one should consider a balance between natural and social / cultural components. As such, this research used six types of data related to: relief, climate, land cover, tourism forms, main settlements, and internal protected areas. These resulted in 23 variables (Table 1).

For this study, the Digital Elevation Model was created using the 1:25,000 topographic map (1970 edition), in GIS environment, to explore the specific characteristics of the relief.

The climate item was calculated based on the average monthly multiannual temperature and rainfall from the period between 1970 and 2000 (based on data provided by WorldClim, 2020).

According to the CORINE Land Cover (CLC) nomenclature, level 3 was used, of which only the classes relevant to this study were included. For example, the discontinuous urban fabric class was excluded, given the scattered nature of the settlements and the difficulty of capturing them at this resolution. They have been replaced by another technique described below. For the same reasons, rivers were excluded from the analysis. In this regard, as noted by Brabyn (2009), "in a mountainous context, river information is superfluous because every mountain valley has a river, while the large braided rivers on the plains have a more significant impact on landscape character" (p. 310). Instead, Fântânele Reservoir was considered the main hydrographic element. The land cover data set was retrieved from Copernicus Land Monitoring Service (2018). Based on orthophotoplans, 
the native settlements were digitized in point features (shapefile format) without any differentiation between the main dwellings and other farm-related constructions. However, the permanent sheepfolds could be easily identified, therefore they were included in the study as a distinct category.

Table 1. Variables, formats and the corresponding units.

\begin{tabular}{|c|c|c|c|}
\hline No. & Variable & Format & Unit \\
\hline 1 & $\begin{array}{l}\text { Multiannual monthly } \\
\text { average temperature }\end{array}$ & Raster & Multiannual monthly average temperature \\
\hline 2 & $\begin{array}{l}\text { Multiannual monthly } \\
\text { average rainfall }\end{array}$ & Raster & Multiannual monthly average rainfall \\
\hline 3 & Elevation & Raster & Mean \\
\hline 4 & Broad-leaved forest & Polygon & Proportion $(\%)$ \\
\hline 5 & Coniferous forest & Polygon & Proportion (\%) \\
\hline 6 & Mixed forest & Polygon & Proportion (\%) \\
\hline 7 & Natural grasslands & Polygon & Proportion (\%) \\
\hline 8 & Water bodies & Polygon & Proportion $(\%)$ \\
\hline 9 & Restaurants & Point & Weighted point density, $1,5 \mathrm{~km}^{2}$ cell size with rectangle neighbourhood \\
\hline 10 & $\begin{array}{l}\text { Tourist accommodation } \\
\text { units }\end{array}$ & Point & Weighted point density, $1,5 \mathrm{~km}^{2}$ cell size with rectangle neighbourhood \\
\hline 11 & Equestrian tourism & Point & Weighted point density, $1,5 \mathrm{~km}^{2}$ cell size with rectangle neighbourhood \\
\hline 12 & Festival and event tourism & Point & Weighted point density, $1,5 \mathrm{~km}^{2}$ cell size with rectangle neighbourhood \\
\hline 13 & Fishing tourism & Point & Weighted point density, $1,5 \mathrm{~km}^{2}$ cell size with rectangle neighbourhood \\
\hline 14 & Nautical tourism & Point & Weighted point density, $1,5 \mathrm{~km}^{2}$ cell size with rectangle neighbourhood \\
\hline 15 & $\begin{array}{l}\text { Cultural, historical, and } \\
\text { religious tourism }\end{array}$ & Point & Weighted point density, $1,5 \mathrm{~km}^{2}$ cell size with rectangle neighbourhood \\
\hline 16 & Agritourism & Point & Weighted point density, $1,5 \mathrm{~km}^{2}$ cell size with rectangle neighbourhood \\
\hline 17 & Hiking tourism & Polyline & Weighted point density, $1,5 \mathrm{~km}^{2}$ cell size with rectangle neighbourhood \\
\hline 18 & Speleological tourism & Point & Weighted point density, $1,5 \mathrm{~km}^{2}$ cell size with rectangle neighbourhood \\
\hline 19 & Winter sports tourism & Point & Weighted point density, $1,5 \mathrm{~km}^{2}$ cell size with rectangle neighbourhood \\
\hline 20 & $\begin{array}{l}\text { Nature reserves and nature } \\
\text { monuments }\end{array}$ & Polygon & Proportion $(\%)$ \\
\hline 21 & Integral protection area & Polygon & Proportion $(\%)$ \\
\hline 22 & Native settlements & Point & Absolute number \\
\hline 23 & Permanent sheepfolds & Point & Absolute number \\
\hline
\end{tabular}

Regarding the internal management and protected areas, the analysed data included: 52 nature monuments and nature reserves, and the integral protected area - one of the four categories that could contribute to the purpose of this research. The spatial extension of the two are consistent with Apuseni Nature Park Administration (2016) and Romsilva - National Forest Division (2021).

The data regarding the tourism component consists of eight of the most significant forms of tourism practiced in the studied area, being under the umbrella of the more general rural tourism and ecotourism. However, tourism forms incompatible with the ecotourism concept, as well as the underrepresented ones were excluded. For the purpose of this item, data were collected and categorized from the on-line tourist offers of the classified and unclassified accommodation units and other profile sites, as well as from official sources (Ministry for Economy, Energy and Business Environment of Romania [MEEBE], 2020a, 2020b).
As such, each point feature may represent either tourism facilities, tourism services, or events corresponding to one or more forms of tourism. Next, against the availability and / or seasonality and magnitude criteria, a prioritization framework was designed to differentiate (from 1 to 3 points) the analysed tourist services / infrastructure / events. For example, winter sports tourism will accumulate maximum values in the case of ski slopes, ski lifts and chairlifts, whereas rental services of corresponding sports equipment provided by accommodation units will receive minimum values.

Once the data preparation was completed, the resulted variables were assigned to polygon grid cells, constituting the spatial unit of the further analysis. According to Van Eetvelde and Antrop (2009), the use of grid cells has the advantage of avoiding the creation of slivers (p. 164). Therefore, a variety of grid cell dimensions have been used so far: $2 \mathrm{~km}^{2}$ for the Czech Republic (Chuman and Romportl, 2010), $10 \mathrm{~km}^{2}$ for 
Central Europe (Fňukalová and Romportl, 2014), 1 km² in the case of Belgium (Van Eetvelde and Antrop, 2009). For this study, taking into account the type of data, a $1.5 \mathrm{~km} \times 1.5 \mathrm{~km}$ grid cell size was considered the optimum solution.

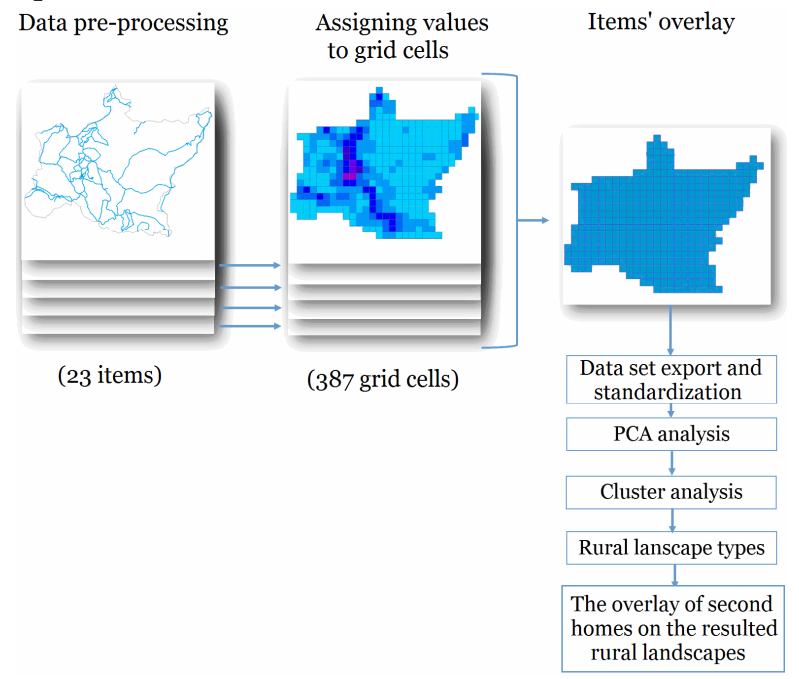

Fig. 2. Main steps in the method used for the typology of the contemporary landscapes in Apuseni Nature Park.

On completion of the assignment of each cell the values of the corresponding variables by Statistical Zonal tool, the resulting data were transferred from the table to excel. Prior to the dimensionality reduction of the original variables, the data were standardized. Following this, the standardized data were the subject of the Principal Component Analysis (PCA) and Varimax rotation with Kaiser Normalization in SPSS software.

The number of components was determined according to eigenvalues larger than 1.00, whereas the results of the principal components were interpreted taking into account the loadings with values greater than 0.50 (in line with the recommendation of Norris et al., 2012). Subsequently, in order to group the observations (i.e. the 387 grid cells with the size of $1 \mathrm{~km}$ $\times 1 \mathrm{~km}$ ), the resulted score was subjected to unsupervised K-means cluster analysis (Fig. 3).

As Yang et al. (2020, p. 4) stated, "in the parametric approach, multivariate analysis and cluster analysis are common use to determine the landscape classification [...], for instance, the combination of principal component analysis (PCA) and cluster analysis" (for more details, see also Fňukalová and Romportl, 2014; Pecher et al., 2013). Because the variable 'water' (i.e. Fântânele Reservoir) was not highly loading on any components, it was used for cluster analysis. Finally, the spatial join based on the location of the resulted clusters and second homes was performed. As such, each grid cell contains the sum of the second homes of the location in question. The second homes were identified during field visits.

The boundary of the geographical area studied was taken from the Ministry of the Environment, Waters, Forests of Romania (2015). However, for the purpose of this research, the limit used does not fit fully with the official one. Likewise, the counties' administrative boundaries were downloaded from the National Agency for Cadastre and Real Estate Advertising of Romania (2020).

\section{RESULTS AND DISCUSSION}

The results of the Principal Components Analysis indicate seven extracted factors with eigenvalues equal to or greater than 1.00 (in line with the recommendation of Norris et al., 2012), explaining 77.2\% of the total variance. Likewise, the Varimax rotation of the components was converged in six iterations. The Kaiser-Meyer-Olkin (KMO) Test was 0.684, whereas the Bartlett's Test of Sphericity was highly significant ( $\mathrm{p}$-value $<0.000)$.

Table 2. The resulted component loadings of the variables used after Varimax rotation with Kaiser Normalization.

\begin{tabular}{|l|r|r|r|r|r|r|r|}
\hline \multirow{2}{*}{\multicolumn{1}{|c|}{ Variables }} & \multicolumn{7}{c|}{ Component } \\
\cline { 2 - 8 } & \multicolumn{1}{|c|}{$\mathbf{1}$} & \multicolumn{1}{c|}{$\mathbf{2}$} & \multicolumn{1}{c|}{$\mathbf{3}$} & \multicolumn{1}{c|}{$\mathbf{5}$} & $\mathbf{6}$ & $\mathbf{7}$ \\
\hline $\begin{array}{l}\text { Multiannual monthly } \\
\text { average temperature }\end{array}$ & $\mathbf{- 0 . 9 5 8}$ & -0.004 & 0.034 & 0.142 & -0.064 & -0.015 & -0.111 \\
\hline Elevation & $\mathbf{0 . 9 3 8}$ & -0.019 & -0.042 & -0.182 & 0.064 & 0.009 & 0.139 \\
\hline $\begin{array}{l}\text { Multiannual monthly } \\
\text { average rainfall }\end{array}$ & $\mathbf{0 . 9 1 0}$ & -0.006 & -0.044 & -0.211 & 0.119 & 0.008 & 0.166 \\
\hline Broad-leaved forest & $\mathbf{- 0 . 8 1 2}$ & 0.015 & -0.028 & -0.286 & 0.184 & -0.120 & 0.013 \\
\hline Coniferous forest & $\mathbf{0 . 6 6 9}$ & -0.040 & -0.003 & -0.042 & -0.123 & $\mathbf{- 0 . 5 5 9}$ & -0.211 \\
\hline Winter sports tourism & 0.015 & $\mathbf{0 . 9 2 9}$ & -0.005 & 0.011 & -0.050 & 0.007 & 0.017 \\
\hline Restaurants & -0.018 & $\mathbf{0 . 8 4 3}$ & 0.325 & 0.056 & -0.025 & -0.013 & 0.000 \\
\hline $\begin{array}{l}\text { Tourist accommodation } \\
\text { units }\end{array}$ & -0.046 & $\mathbf{0 . 8 3 2}$ & 0.210 & 0.417 & -0.024 & -0.001 & -0.042 \\
\hline Equestrian tourism & 0.001 & $\mathbf{0 . 6 8 5}$ & 0.045 & $\mathbf{0 . 5 4 8}$ & 0.014 & -0.011 & -0.079 \\
\hline
\end{tabular}


Spatial Patterns of Second Home Development as Part of Rural Landscapes. A Case Study of Apuseni Nature Park Journal of Settlements and Spatial Planning, Special Issue, no. 8 (2021) 65-77

Territorial Identities and Sustainable Development. Challenges and Solutions

\begin{tabular}{|l|r|r|r|r|r|r|r|}
\hline Festival and event tourism & 0.013 & 0.127 & $\mathbf{0 . 9 2 4}$ & 0.093 & -0.029 & -0.008 & 0.069 \\
\hline Fishing tourism & -0.008 & 0.145 & $\mathbf{0 . 9 1 5}$ & 0.052 & -0.038 & 0.005 & -0.042 \\
\hline Nautical tourism & -0.074 & 0.110 & $\mathbf{0 . 8 5 0}$ & 0.091 & 0.045 & -0.016 & -0.019 \\
\hline Native settlements & -0.132 & 0.092 & 0.046 & $\mathbf{0 . 8 5 9}$ & -0.099 & 0.095 & 0.104 \\
\hline $\begin{array}{l}\text { Cultural, historical, and } \\
\text { religious tourism }\end{array}$ & -0.088 & 0.132 & 0.138 & $\mathbf{0 . 7 8 8}$ & -0.028 & -0.063 & 0.056 \\
\hline Agritourism & -0.051 & 0.497 & 0.065 & $\mathbf{0 . 6 6 9}$ & 0.032 & -0.007 & -0.076 \\
\hline Integral protection area & 0.171 & -0.003 & -0.015 & -0.149 & $\mathbf{0 . 8 2 8}$ & 0.084 & 0.035 \\
\hline $\begin{array}{l}\text { Nature reserves and } \\
\text { nature monuments }\end{array}$ & -0.183 & -0.014 & -0.011 & -0.018 & $\mathbf{0 . 7 9 2}$ & -0.053 & 0.000 \\
\hline Hiking tourism & 0.126 & 0.060 & 0.019 & -0.055 & $\mathbf{0 . 6 4 0}$ & $\mathbf{0 . 5 0 3}$ & 0.122 \\
\hline Speleological tourism & -0.011 & -0.067 & -0.002 & 0.063 & $\mathbf{0 . 5 9 9}$ & 0.021 & -0.182 \\
\hline Mixed forest & 0.046 & -0.040 & -0.025 & 0.022 & 0.077 & $\mathbf{0 . 9 2 3}$ & -0.191 \\
\hline Natural grasslands & 0.099 & -0.076 & -0.040 & 0.217 & -0.027 & -0.072 & $\mathbf{0 . 7 8 2}$ \\
\hline Permanent sheepfolds & 0.093 & 0.009 & 0.033 & -0.081 & -0.058 & -0.020 & $\mathbf{0 . 6 3 0}$ \\
\hline
\end{tabular}

* The highest component loadings values are given in bold-face.

The interpretation of the results highlighted in Table 2 is as follows:

Component 1. "Wild, high altitude forested areas" - high component values are recorded in areas with low average multiannual monthly temperature, high average multiannual monthly rainfall, and high average elevation, and generally, a large proportion of coniferous forests.

Component 2. "Highly developed winter destinations" - high values of the component occur in areas with a high score in terms of tourism facilities and services related to winter sports. Similarly, in these areas, the capacity of restaurants and tourist accommodation units (classified and unclassified) is considerably large. There are also opportunities for equestrian tourism.

Component 3. "Festival, event and wateroriented tourism destinations" - high component values are achieved by areas where the forms of festival and event tourism acquired the highest accumulated score, followed by tourism services and facilities corresponding to fishing and water sports.

Component 4. "Cultural and agritourismoriented areas" - high component values appear in areas with more compact structure of native settlements, complemented by considerable opportunities for cultural tourism and agritourism. Tourism services and facilities related to equestrian activities may also be found here.

Component 5. "Ecologically-important areas" - high component values are recorded in areas with large proportion of internal protected areas and integral protection area, respectively, high density of approved tourist paths and great accumulated score regarding speleological tourism.

Component 6. "Recreational areas with mixed forests" - high values for this component are characteristic of areas with large share of mixed forest and relatively high density of approved tourist paths.

Component 7. "Natural, pastoral areas" - high component values are recorded in areas with large proportion of natural grasslands and concentrations of permanent sheepfolds in certain areas.

Following the cluster analysis of the principal component scores, 19 types of rural landscape resulted (Fig. 3).

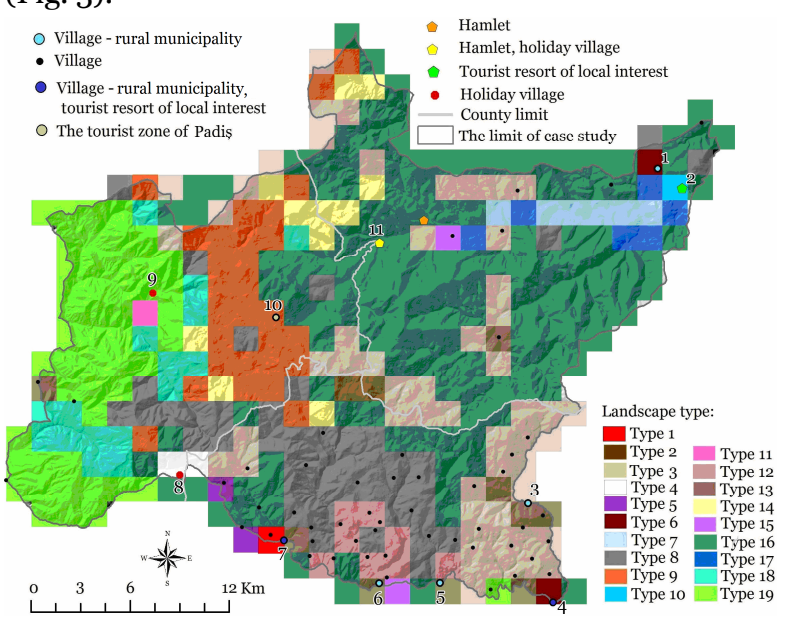

Fig. 3. Types of rural landscapes in the Apuseni Nature Park: 1 - Beliș; 2 - Fântânele resort; 3 - Horea; 4 Albac; 5 - Scărişoara; 6 - Gârda de Sus; 7 - Arieșeni; 8 Vârtop; 9 - Boga; 10 - Padiș.

Type 1. "Densely built-up landscape with mixed tourism opportunities" - covers $2.25 \mathrm{~km}^{2}$ (0.3\% of the total analysed area) of the municipality and resort of local interest: Arieşeni (no. 7 in Fig. 3). Considering the proximity to the Vârtop ski resort (no. 8 in Fig. 3), the village is the second most developed location for winter sports services (e.g. ski equipment rental, ski instructor courses, etc.). In addition, the overall capacity of restaurants and tourist accommodation units is significantly higher compared to other areas. 
Moreover, the accommodation providers offer additional services to equestrian activities (i.e. riding lessons, horse-drawn cart, carriage or sledge rides). The high density of locals' constructions is doubled by the presence of general infrastructure (shops, post office, human dispensary, etc.) and material and immaterial cultural elements (e.g. church, country fair), which increase the opportunities for religious and cultural tourism. Also, the most common agritourism services in this pattern are the processing and the sale of local products, as well as the educational farm. This type of landscape comprises six second homes (i.e. $0.6 \%$ of the total) with great accessibility to a wide range of local products and services.

Type 2. "Cultural pasture landscape" comprises $4.5 \mathrm{~km}^{2}$ (0.5\% of the total analysed area). The area impresses with the genuine mixture of natural grassland with permanent sheepfolds, bordered by coniferous forests. Nevertheless, there are other cultural elements such as a traditional fair and a monastery. Based on land-use regulation and the nature and landscape protection measures respectively, no form of second home ownership has been identified in this type of landscape.

Type 3. "Wild or ordinary rural areas" covers $1,19.25 \mathrm{~km}^{2}$ (13.7\% of the total analysed area) and has two façades. On the one hand, it is an uninhabited area, at high altitudes, with harsher climatic conditions, and with large proportions of grassland bordered by coniferous forests (northwestern border of the study area in Fig. 3). On the other hand, it is an area with households scattered on mountain plateaus with grassland bordered by coniferous forests. To a lesser extent, some areas include permanent sheepfolds. In this pattern, tourism facilities or services of any kind are underrepresented. However, there are 82 second homes (8.5\%) located in the areas of native settlements. These settlements belong to the so-called 'disappearing regions' (Müller, 2004) and shall comprise, in certain areas, inherited or acquired converted former permanent rural housing.

Type 4. "Winter sports landscape" - comprises $4.5 \mathrm{~km}^{2}$ (0.5\% of the total analysed area) and encompasses the Vârtop ski resort. The pattern holds the most developed tourist infrastructure in the entire area (three ski slopes equipped with ski lift or chairlift, winter sports equipment rental, about 1,205 accommodation places and 836 restaurant seats, etc. according to MEEBE, 2020a, 2020b; Ciupe, 2020). The resort is located at high elevation in a setting with coniferous forests but also, to a small extent, mixed ones. This pattern belongs to the hot spot tourist areas (Müller, 2004) represented mainly by popular winter resorts (according to the international experience described in subchapter 2.1.), where the purpose-built second homes (in our case, 59 - meaning $6.1 \%$ of the total) are more likely to be rented to traditional tourists, relatives or friends (Ciupe, 2020; Komppula, Reijonen and Timonen, 2008; Nicod, Mungall and Henwood, 2007).

Type 5. "Areas with low intensity of mixed tourism opportunities" - covers $4.5 \mathrm{~km}^{2}$ (0.5\% of the total analysed area) of the area between Arieșeni and Vârtop resorts (from 7 to 8 in Fig. 3). This gives it an intermediate character between the two landscape types (type 1 and type 4$)$. There are a number of $20(2.1 \%)$ purpose-build second homes located in areas with high road accessibility primarily due to the entertainment and winter sports facilities.

Type 6. "Commune centres with developed cultural, religious tourism, and agrotourism" includes a total of $4.5 \mathrm{~km}^{2}$ (0.5\% of the total analysed area) of two rural municipalities: Beliş (Cluj county, no. 1 in Fig. 3) and Albac (Alba county, no. 4 in Fig. 3). The common features in the pattern are: the nucleated structure of the settlements, the high score of services and facilities particular to historical, cultural and religious tourism, agritourism (the latter earning the highest score in Albac), and equestrian tourism. The most surprising aspect is the discrepancy in the share of second homes between the two villages (Fig. 4), namely, 129 in Beliș village compared to only one in Albac.

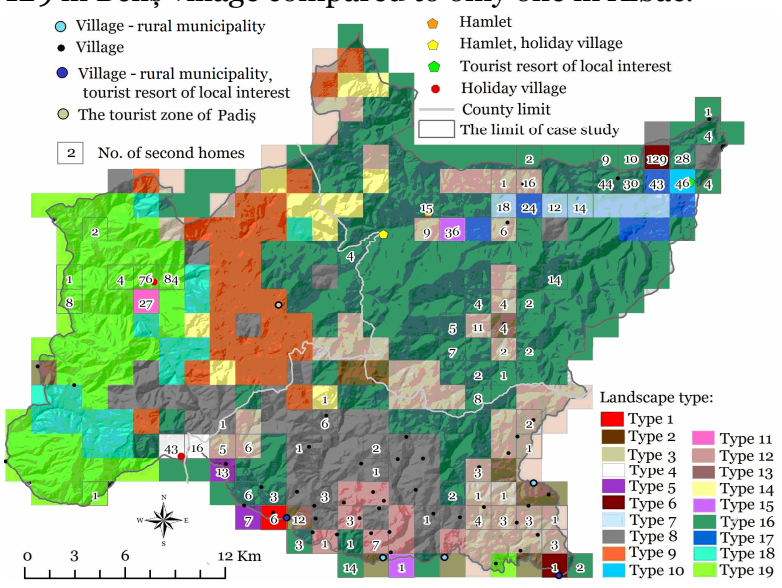

Fig. 4. Spatial distribution of second homes in relation to the rural landscapes in the Apuseni Nature Park.

Considering the second home owners' place of origin from the two locations, Beliș village falls in the weekend zone, whereas Albac village in the vacation area. As such, the hypothesis according to which distance influences the number of second houses is confirmed for these circumstances.

Type 7. "Natural amenity-rich, lakeside landscapes" - contains $13.5 \mathrm{~km}^{2}$ (1.6\% of the total analysed area) of natural landscape in which the water element is present in a large proportion (i.e. Fântânele reservoir). Tourism facilities and services of any kind are less-developed in these areas. There are 44 second homes (4.6\%) located on the lake shore, attracted by the tranquillity and scenery specific to the area.

Type 8. "Amenity-rich rural area" - comprises $96.7 \mathrm{~km}^{2}$ (11.1\% of the total analysed area) of the areas 
with dispersed villages, high proportions of mixed forest, and high density of approved tourist paths. Other tourism facilities and services are poorly represented. This type of landscape accumulated a total of 15 second homes located in inhabited areas (1.6\%).

Type 9. "Touristic, ecologically-important areas" - covers $65.25 \mathrm{~km}^{2}$ (7.5\% of the total analysed area) in the areas with the highest average elevation, with a large share of reservations and natural monuments, and integral protection area, as well as with a high density of approved tourist paths complemented by great opportunities for speleological tourism. As in the case of type 2, due to the spatial planning regulation, the second homes are completely missing in these settings.

Type 10. "Lakeside resort landscapes" includes $2.25 \mathrm{~km}^{2}$ (0.3\% of the total analysed area) of the Fântânele lakeside resort (no. 2 in Fig. 3). The pattern stands out with the highest score regarding the festival and event tourism. Apart from that, tourist infrastructure related to fishing and nautical tourism is well represented (e.g. boat rides, boat rentals). However, the possibilities for accommodation and public catering are very limited. The resort is located in a natural setting, away from permanent settlements, in a mixture of elements such as water, coniferous forest and, to a lesser extent, mixed forest. This pattern comprises 46 high standard second homes (4.8\%).

Type 11. "Forested, remote areas with low tourism infrastructure" - includes $2.25 \mathrm{~km}^{2}(0.3 \%$ of the total analysed area) of the southern part of the holiday village Boga (no. 9, Fig. 3). This natural landscape is distinguished by low average elevation, and high proportion of broad-leaved forest. Also, there are very moderate opportunities for event tourism (e.g. Boga Gastronomic Festival), water sports (organized rafting on the Crișul Pietros Valley) and trekking tourism. Despite this, the capacity for tourist accommodation and public catering are under-represented. This pattern includes 27 second homes (2.8\%).

Type 12. "Cultural and ecological remote landscapes" - comprises $18 \mathrm{~km}^{2}$ (2.1\% of the total analysed area) of areas with mixed forest and relatively high density of approved tourist paths. The structure of the settlements is generally dispersed. In this pattern, the opportunities for recreational activities specific to cultural, religious and historical tourism, agritourism, and speleological tourism are at average levels. This type of landscape hosts 11 second homes (1.1\%).

Type 13. "Densely built-up rural villages with moderate opportunities for cultural tourism and agritourism" - covers $20.25 \mathrm{~km}^{2}$ (2.3\% of the total analysed area) of the nucleated settlements (see nos. 3, 5, 6 in Fig. 3). In these areas, opportunities for agritourism or cultural activities prevail. However, due to the densely build-up areas, there are only 16 (1.7\%) second homes.
Type 14. "Ordinary, densely build-up rural areas" - comprises $24.75 \mathrm{~km}^{2}$ (2.8\% of the total analysed area) of areas with the largest share of the surface of nature monuments and nature reserves covered by coniferous forests at relatively high altitudes and harsh climate. There is only one second home (0.1\%).

Type 15. "Ordinary villages with opportunities for festivals and other cultural events" covers $4.5 \mathrm{~km}^{2}$ (0.5\% of the total analysed area) of the permanently inhabited areas that stand out primarily through opportunities for tourism of events and festivals (e.g. Smida Jazz Festival). However, as in type 6 , the factor underlying the difference in the number of second homes between the two cases (36 compared to 1, see Fig. 4) is the distance from the main residence.

Type 16. "Forested, remote amenity-rich area" - comprises $324 \mathrm{~km}^{2}$ (37.2\% of the total analysed area). The average elevation is high, relatively harsh climate, and larger surfaces of coniferous forests. The constructions of the locals and the tourist infrastructure are negligible. This type of landscape attracted 227 (23.5\%) second homes located in the vicinity of permanent settlements.

Type 17. "Lakeside areas with minimum tourism infrastructure" - extends over $13.5 \mathrm{~km}^{2}(1.6 \%$ of the total analysed area). The pattern comprises significant areas of Fântânele Reservoir in which, compared to type 7 , rafting is the main activity that may be practiced. A total of 67 (7\%) second homes are built on the lakeside.

Type 18. "Karst landscapes" - comprises 36 $\mathrm{km}^{2}$ (4.1\% of the total analysed area) of areas with the highest potential for speleological tourism, low average elevation, and high proportion of broad-leaved forests. There are no second homes.

Type 19. "Broad-leaved forests, remote natural areas" - comprises $110.25 \mathrm{~km}^{2}(12.7 \%$ of the total analysed area) of areas with the lowest average elevation, the mildest climatic conditions, a significant proportion of broad-leaved forest, and a reduced density of tourist infrastructure. In the pattern, there are 176 second homes (18.3\%), of which most are in Boga Holiday Village (northern side, no. 9 in Fig. 3).

\section{CONCLUSIONS}

The present study was designed to determine the main directions of the spatial development of second homes in a detailed approach. Overall, our results regarding second homes' spatial differentiation are broadly consistent with the international experience.

By using the multivariate classification analysis of landscapes, these findings provide additional information with respect to the spatial distribution of second homes in relation to the various rural landscapes. Therefore, the results of this study indicate 
that second home development is characteristic of amenity-high remote areas, popular tourist areas, as well as inside permanent settlements. However, the second home phenomenon is not included in the tourism development strategies and is only covered by land-use regulation and the nature and landscape protection measures.

The decision factors should consider the change in local socio-cultural and economic dynamics and, consequently, the new rural reality. Simultaneously, there is a need to promote a sustainable development policy in which the second home developments to be spatially, structurally, and functionally integrated in in the local landscapes. In this regard, my research has shown that the spatial distribution of second homes points out great opportunities for capitalization of both general and tourist services. By diversifying, promoting and directing tourist services to second home owners (Ciupe, 2021), local resources could be harnessed in a sustainable way. Therefore, the results provide a basis for integrated planning and sustainable development.

However, important limitations need to be considered. First, the generalisability of these results is subject to certain limitations. Second, although the study used free data, their processing can be time consuming. Third, the process of selecting and processing data may involve a high degree of subjectivity.

Future investigations are necessary to further validate the conclusions of this study. For instance, in order to achieve a more comprehensive picture, future research should focus on the investigation of the location factors of second home ownership using, for example, the regression method.

\section{REFERENCES}

Adamiak C. (2014), Importance of second homes for local economy of a rural tourism region. Conference Proceedings of International Antalya Hospitality Tourism and Travel Research Conference, Turkey, 360370.

URL:

https://www.academia.edu/12753324/Importance_of_ second_homes_for_local_economy_of_a_rural_touris m_region. Accessed on 15.01.2021.

Adamiak C. (2016), Cottage sprawl: spatial development of second homes in Bory Tucholskie, Poland. Landscape and Urban Planning, 147, 96-106. DOI:

http://dx.doi.org/10.1016/j.landurbplan.2015.11.003.

Apuseni Nature Park Administration (2016), Plan de management al Parcului Natural Apuseni şi al Siturilor Natura 2000: ROSCIooo2 Apuseni, ROSCIo016 Buteasa şi ROSPAoo81 Munţii Apuseni Vlădeasa [Management Plan of the Apuseni Nature Park and Natura 2000 Sites: ROSCIooo2 Apuseni,
ROSCIO016 Buteasa and ROSPAoo81 Apuseni Mountains - Vlădeasa]. URL: http://www.anpm.ro/documents/17647/o/Plan+de+m anagement+noiembrie+2016.pdf/e105ff27-9do3-450986da-61a5721d2fec. Accessed on 16.01.2021.

Banini T., Ilovan O.-R. (2021a), Introduction: dealing with territorial/place identity representations. In: Banini T., Ilovan O.-R. (eds.), Representing Place and Territorial Identities in Europe. GeoJournal Library, vol. 127. Springer, Cham, 1-19. DOI: https://doi.org/10.1007/978-3-030-66766-5_1.

Banini T., Ilovan O.-R. (2021b), Conclusions: towards a new agenda for place/territorial identity research. In: Banini T., Ilovan O.-R. (eds.), Representing Place and Territorial Identities in Europe. GeoJournal Library, vol. 127. Springer, Cham, 251-265, DOI: https://doi.org/10.1007/978-3-030-66766-5_17.

Boțan C. N., Ilovan O.-R. (2006), Geographic identity aspects of the Land of the Moți. In International Conference of Territorial Intelligence, Sep 2006, Alba Iulia, Romania, 87-93. URL: https://halshs.archives-ouvertes.fr/halshs-00516049.

Accessed on 27.02.2021.

Brabyn L. (2009), Classifying landscape character. Landscape Research, 34(3), 299-321. DOI: 10.1080/01426390802371202.

Chou Y. H. (1995), Spatial pattern and spatial autocorrelation. In: Frank A.U., Kuhn W. (eds.), Spatial Information Theory. A Theoretical Basis for GIS. COSIT 1995. Lecture Notes in Computer Science, vol. 988. Springer, Berlin, Heidelberg, 365-376. DOI: https://doi.org /10.1007/3-540-60392-1_24.

Chuman T., Romportl D. (2010), Multivariate classification analysis of cultural landscapes: an example from the Czech Republic. Landscape and Urban Planning, 98(3), 200-209. DOI: 10.1016/j.landurbplan.2010.08.003.

Ciupe I. Al. (2020), Analiză spațială a relației dintre structurile de primire turistică cu funcțiuni de cazare și casele de vacanță (locuințele secundare). Studiu de caz: Parcul Natural Apuseni [Spatial analysis of the relationship between tourist accommodation establishments and second homes. A case study: Apuseni Nature Park] [Chapter in Romanian]. In: Ilovan O.-R. (ed.), Reziliență și Dezvoltare Durabilă [Resilience and Sustainable Development]. Presa Universitară Clujeană, Cluj-Napoca, 187-216.

Ciupe I. Al. (2021), Linking Second Home Tourism to Compatible Tourism Resources: A Sustainable Solution for Preserving Local Character in the Apuseni Nature Park. Presa Universitară Clujeană, Cluj-Napoca, forthcoming.

Cohen E. (1974), Who is a tourist? A conceptual clarification. The Sociological Review, 22(4), 527-555. DOI: $\quad$ https://doi.org/10.1111/j.1467954X.1974.tboo507.x.

Copernicus Land Monitoring Service (2018), CORINE Land Cover (CLC) 2018, Version 2020_20u1. 
URL: https://land.copernicus.eu/paneuropean/corine-land-cover. Accessed on 20.01.2021. Czarnecki A. (2014), Economically detached? Second home owners and the local community in Poland. Tourism Review International, 18(3), 153-166. DOI: 10.3727/154427214X14101901317110.

Czarnecki A., Sireni M., Dacko M. (2021), Secondhome owners as consumers of local food. International Journal of Consumer Studies, 45(2), 175-187. DOI: 10.1111/ijcs.12610.

European Commission (EC) (2013), Regulation (EU) No 1305/2013 of the European Parliament and of the Council of 17 December 2013 on support for rural development by the European Agricultural Fund for Rural Development (EAFRD) and repealing Council Regulation (EC) No 1698/2005. URL: https://eurlex.europa.eu/legal-content/EN/TXT/PDF/?uri=CELE $\mathrm{X}: 32013 \mathrm{R} 1305 \&$ from=EN. Accessed on 12.01.2021.

Flognfeldt T., Tjørve E. (2013), The shift from hotels and lodges to second-home villages in mountain-resort accommodation. Scandinavian Journal of Hospitality and Tourism, 13(4), 332-352. DOI: 10.1080/15022250.2013.862440.

Fřukalová E., Romportl D. (2014), A typology of natural landscapes of Central Europe. AUC Geographica, $\quad 49(2), \quad 57-63 . \quad$ DOI: http://dx.doi.org/10.14712/23361980.2014.15.

Hall C. M. (2014), Second home tourism: an international review. Tourism Review International, 18(3). DOI: 10.3727/154427214X14101901317039.

Hall C. M. (2015), Second homes planning, policy and governance. Journal of Policy Research in Tourism, Leisure and Events, 7(1), 1-14. DOI: 10.1080/19407963. 2014.964251.

Hall C. M., Müller D. K. (2004), Introduction: second homes, curse or blessing? Revisited. In: Hall C. M., Müller D. K. (eds.), Tourism, Mobility and Second Homes Between Elite Landscape and Common Ground. Channel View Publication, Clevedon, Buffalo, Toronto, 3-14.

Halseth G. (2004), The 'cottage' privilege: increasingly elite landscapes of second homes in Canada. In: Hall C. M., Müller D. K. (eds.), Tourism, Mobility and Second Homes Between Elite Landscape and Common Ground. Channel View Publication, Clevedon, Buffalo, Toronto, 35-54.

Hiltunen M. J., Rehunen A. (2014), Second home mobility in Finland: Patterns, practices and relations of leisure oriented mobile lifestyle. Fennia, 192(1), 1-22. DOI: $10.11143 / 8384$.

Hoogendoorn G., Visser G., Marais L. (2009), Changing countrysides, changing villages: second homes in Rhodes, South Africa. South African Geographical Journal, 91(2), 75-83. URL: https://www.researchgate.net/publication/235064463 _Changing_country_sides_changing_villages_second
homes_in_Rhodes_South_Africa. Accessed on 10.02 . 2021.

Hoogendoorn G., Visser G. (2004), Second homes and small-town (re)development: the case of Clarens. Journal of Family Ecology and Consumer Sciences, 32, 105-116.

URL:

https://www.ajol.info/index.php/jfecs/article/downloa d/52852/41454. Accessed on 20.02.2020.

International Union for Conservation of Nature (2013), Guidelines for Applying Protected Area Management Categories (Edited by Nigel Dudley), Monographic Series no. 21. DOI: 10.2305/IUCN. CH.2008.PAPS.2.en.

Jaakson R. (1986), Second-home domestic tourism. Annals of Tourism Research, 13(3), 367-391. DOI: https://doi.org/10.1016/0160-7383(86)90026-5.

Jellema A., Stobbelaar D.-J., Groot J. C. J., Rossing A. H. (2009), Landscape character assessment using region growing techniques in geographical information systems. Journal of Environmental Management, 90 Suppl, 2(3), 161-174. DOI: 10.1016/j.jenvman.2008.11.031.

Jeong J. S., García-Moruno L., HernándezBlanco J., Jaraíz-Cabanillas F. J. (2014), An operational method to supporting siting decisions for sustainable rural second home planning in ecotourism sites. Land Use Policy, 41, 550-560. DOI: https://doi.org/10.1016/j.landusepol.2014.04.012.

Kauppila P. (2010), Resorts, second home owners and distance: a case study in Northern Finland. Fennia, 188(2), 163-178. URL: https://www.researchgate.net/publication/49584362_ Resorts_second_home_owners_and_distance_a_case _study_in_northern_Finland. Accessed on 11.01.2020.

Kiss K., Ruszkai C., Szücs A., Koncz G. (2020), Examining the role of local products in rural development in the light of consumer preferencesresults of a consumer survey from Hungary. Sustainability, 12(13), 5473. DOI: 10.3390/su12135473.

Komppula R., Reijonen H., Timonen T. (2008), Vacation home owner's willingness to lease through an intermediary - a case study in two Finnish ski resorts. In: Keller P., Bieger T. (eds.), Real Estate and Destination Development in Tourism: Successful Strategies and Instruments. International Association of Scientific Experts in Tourism (AIEST). Erich Schmidt Verlag, Berlin, 285-299.

Lee J. T., Elton M. J., Thompson S. (1999), The role of GIS in landscape assessment: using land-usebased criteria for an area of the Chiltern Hills Area of Outstanding Natural Beauty. Land Use Policy, 16, 2332. DOI: https://doi.org/10.1016/So2648377(98)ooo33-7.

Marcouiller D. W., Green G. P., Deller S. C., Sumathi N. R, Erkkila D. (1996), Recreational Homes and Regional Development. A Case Study from 
the Upper Great Lakes States. University of Wisconsin Extension, Report No. G3651.

Marescotti A. (2003), Typical products and rural development: who benefits from PDO/PGI recognition? $83^{\text {rd }}$ EAAE SEMINAR Food Quality Products in the Advent of the 21st Century: Production, Demand and Public Policy $4^{\text {th }}-7^{\text {th }}$ September, 2003 - Chania, Greece, 1-17. URL: http://www.fao.org/fileadmin/templates/olq/documen ts/documents/cherry\%20of\%2oLari\%20marescotti.pdf. Accessed on 11.01.2020.

Mchugh K. E. (2006), Citadels in the sun. In: McIntyre N., Williams D. R. \& McHugh K. E. (eds.), Multiple Dwelling and Tourism. Negotiating Place, Home and Identity. CABI, Wallingford, 262-277.

Mchugh K. E. (2007), Generational consciousness and retirement communities. Population, Space and Place, 13(4), 293-306. DOI: 10.1002/psp.448.

Mchugh K. E., Mings R. C. (1996), The circle of migration: attachment to place in aging. Annals of the Association of American Geographers, 86(3), 530-550. DOI: 10.1111/j.1467-8306.1996.tbo1765.x.

Mihalache F. (2020), Mediul rural între 1990 și 2020: Transformări și decalaje [Rural milieu between 1990 and 2020: Transformations and disparities]. Presa Universitară Clujeană, Cluj-Napoca. [Book in Romanian]. ISBN: 978 - 606 - 37 - 0825 - 1.

Mika M. (2013), Spatial Patterns of second homes development in the Polish Carpathians. In: Kozak J., Ostapowicz K., Bytnerowicz A., Wyżga B. (eds.), Integrating Nature and Society Towards Sustainability, Environmental Science and Engineering. Springer, Berlin, Heidelberg, 497512. DOI: 10.1007/978-3-642-12725-0_35.

Ministry for Economy, Energy and Business Environment of Romania [MEEBE] (2020a), Classified tourist reception structures with accommodation functions. Updated version of 17.07.2020. URL: http://turism.gov.ro/web/autorizareturism/. Accessed on 18.07.2020.

Ministry for Economy, Energy and Business Environment of Romania (2020b), Classified tourist reception structures with public catering functions. Updated version of 11.09.2020. URL: http://turism.gov.ro/web/autorizare-turism/. Accessed on 18.07.2020.

Ministry of the Environment, Waters, Forests of Romania (2015), Date GIS [GIS Data]. URL: http://www.mmediu.ro/articol/date-gis/434. Accessed on 01.01.2021.

Mirani S. Z., Farahani B. M. (2015), Second homes tourism and sustainable rural development in all around the world. International Journal of Leisure and Tourism Marketing, 4(3/4), 176-188. DOI: 10.1504/IJLTM.2015.072076.

Müller D. K. (2004), Second homes in Sweden: patterns and issues. In: Hall C. M., Müller D. K. (eds.), Tourism, Mobility and Second Homes: Between Elite 76
Landscape and Common Ground. Channel View Publication, Clevedon, Buffalo, Toronto, 244-258.

Müller D. K., Hall C. M., Keen D. (2004), Second Home Tourism Impact, Planning and Management. In: Hall C. M., Müller D. K. (eds.) Tourism, Mobility and Second Homes Between Elite Landscape and Common Ground. Channel View Publication, Clevedon, Buffalo, Toronto, 15-32.

Müller D. K., Hall C. M. (2004), The Future of Second Home Tourism. In: Hall C. M., Müller D. K. (eds.) Tourism, Mobility and Second Homes: Between Elite Landscape and Common Ground. Channel View Publication, Clevedon, Buffalo, Toronto, 273-278.

Müller D. K. (2002a), Second home ownership and sustainable development in Northern Sweden. Tourism and Hospitality Research, 3(4), 343-355. DOI: 10.1177/146735840200300406.

Müller D. K. (2002b), German second homeowners in Sweden. Some remarks on the tourism - migration nexus. Revue Européenne des Migrations Internationals, 18(1). DOI: 10.400o/remi.1684.

Müller D. K. (2005), Second home tourism in the Swedish Mountain Range. In: Hall C. M., Boyd S. (eds.), Nature-based Tourism in Peripheral Areas: Development or Disaster? Channel View Publication, Clevedon, Buffalo, Toronto, 133-148.

Müller D. K. (2006), The attractiveness of second home areas in Sweden: a quantitative analysis. Current Issues in Tourism, 9(4-5), 335-350. DOI: http://dx.doi.org/10.2167/cit269.o.

National Agency for Cadastre and Real Estate Advertising of Romania (2020), Descărcare limite administrative [Download administrative boundaries]. URL:

https:/geoportal.ancpi.ro/portal/apps/webappviewer/ index.html?id=faeba2d173374445b1f13512bd477bb2.

Accessed on 04.01.2021.

Nicod P., Mungall A., Henwood J. (2007), Selfcatering accommodation in Switzerland. Hospitality Management, 26(2), 244-262. DOI: 10.1016/j.ijhm.2006.10.004.

Norris G., Qureshi F., Howitt D., Cramer D. (2012), Introduction to Statistics with SPSS for Social Science. First Edition. Routledge, London. ISBN: 9781408237595.

Paris C. (2006), Multiple 'homes', dwelling \& hypermobility \& emergent transnational second home ownership. Workshop 24. ENHR Conference - Housing in an expanding Europe: theory, policy, participation and implementation. Ljubljana, Slovenia. URL: http://citeseerx.ist.psu.edu/viewdoc/download?doi=10.1 .1.116.657\&rep=rep1\&type=pdf. Accessed on 15.02. 2019. Paris C. (2011), Affluence, Mobility and Second Home Ownership. Routledge, London and New York. ISBN: 978-0-203-84650-6 (ebk).

Pecher C., Tasser E., Walde J., Tappeiner U. (2013), Typology of Alpine region using spatial-pattern 
indicators. Ecological Indicators, 24, 37-47. DOI: https://doi.org/10.1016/j.ecolind.2012.05.025.

Pitkänen K. (2008), Second-home landscape: the meaning(s) of landscape for second-home tourism in Finnish Lakeland. Tourism Geographies: An International Journal of Tourism Space, Place and Environment, 10(2), 169-192. DOI: 10.1080/14616680802000014.

Renting H., Rossing W. A. H., Groot J. C. J., Van der Ploeg J. D., Laurent C., Perraud D., Stobbelaar D. J., Van Ittersum M. K. (2009), Exploring multifunctional agriculture. A review of conceptual approaches and prospects for an integrative transitional framework. Journal of Environmental Management, 90 Suppl 2(1), 112-123. DOI: https://doi.org/10.1016/j.jenvman.2008.11.014.

Roca M. N., Oliveira J. A., Roca Z., Costa L. (2011), Second homes in Portugal: conceptual issues and findings of desk and field research. 2nd International Workshop on Lifestyle Migration and Residential Tourism, Madrid, March 25, 2011. URL: http://www.congresos.cchs.csic.es/lifestylemigration/sites/congresos.cchs.csic.es.lifestylemigration/files/Paper\%2oMaria\%2oNazar\%C3\%A9\%2 oRoca,\%20Jose\%20Antonio\%2oOliveira,\%2oZoran\%2 oRoca\%20\&\%20Luis\%2oCosta.pdf. Accessed on 20.02.2020.

Romsilva - National Forest Division (2021), Zonare internă ale parcurilor naționale şi naturale [Internal Zoning of National and Natural Parks]. URL: https://gis.rosilva.ro/Zonare/\#7/46.045/24.448.

Accessed on 16.01.2021.

Sievänen T., Pouta E., Neuvonen M. (2007), Recreational home users - potential clients for countryside tourism? Scandinavian Journal of Hospitality and Tourism, 7(3), 223-242. DOI: $10.1080 / 15022250701300207$.

Smailes P. J. (2002), From rural dilution to multifunctional countryside: some pointers to the future from South Australia. Australian Geographer, 33(1), 79-95. DOI: 10.1080/00049180220125024.
Soszyński D., Tucki A., Krukowska R., Jaruga C. (2017), Problems of second-home spatial development in protected areas. Polesie National Park case study. Folia Turistica, 44, 49-62. DOI: 10.5604/01.3001.0010.8727.

Soto M. T. R., Clavé S. A. (2017), Second homes and urban landscape patterns in Mediterranean coastal tourism destinations. Land Use Policy, 68, 117-132. DOI: 10.1016/j.landusepol.2017.07.018.

Surd V., Constantin V., Nicula A.-S. (2017), Așezările din Munții Apuseni [Settlements in the Apuseni Mountains]. Presa Universitară Clujeană, Cluj-Napoca. [Book in Romanian]. ISBN: 978-606-37-0096-5.

Surd V., Zotic V., Puiu V., Moldovan C. (2007), Riscul demografic în Munții Apuseni [Demographic Risk in the Apuseni Mountains]. Presa Universitară Clujeană, Cluj-Napoca. [Book in Romanian]. ISBN: 978-973-610-2.

United Nations (2008), Spatial Planning: Key Instrument for Development and Effective Governance with Special Reference to Countries in Transition. Report number: $\quad \mathrm{ECE} / \mathrm{HBP} / 146 . \quad \mathrm{URL}$ : https://unece.org/fileadmin/DAM/hlm/documents/Publi cations/spatial_planning.e.pdf. Accessed on 12.05. 2021.

Van Eetvelde V., Antrop M. (2009), A stepwise multi-scaled landscape typology and characterisation for trans-regional integration, applied on the federal state of Belgium. Landscape and Urban Planning, 91(3), 160-170. DOI: 10.1016/j.landurbplan.2008.12.008.

Wolfe R. I. (1965), About cottages and cottagers. Landscape, 15(1), 6-8.

Woods M. (2005), Rural Geography: Processes, Responses and Experiences in Rural Restructuring. SAGE, Los Angeles, London, New Delhi, Singapore, Washington DC. ISBN: 978-0-7619-4761-5 (pbk).

WorldClim (2020), Historical Climate Data. URL: https://www.worldclim.org/data/worldclim21.html. Accessed on 20.01.2021.

Yang D., Gao G., Li L., Van Eetvelde V. (2020), Multi-scaled identification of landscape character types and areas in Lushan National Park and its fringes, China. Landscape and Urban Planning, 201(1-2), 103844. DOI: 10.1016/j.landurbplan.2020.103844. 